\title{
Relationship Between Sleep Quality and Internet Addiction Among College Students in Yogyakarta
}

\author{
Laras Laksita Ningrum \\ Department of Psychology, Faculty of Psychology and Socio- \\ Cultural Sciences \\ Universitas Islam Indonesia \\ Yogyakarta, Indonesia \\ 14320091@students.uii.ac.id
}

\author{
Fitri Ayu Kusumaningrum \\ Department of Psychology, Faculty of Psychology and Socio- \\ Cultural Sciences \\ Universitas Islam Indonesia \\ Yogyakarta, Indonesia \\ fitriayukusumaningrum@uii.ac.id
}

\begin{abstract}
This study aims to analyze the relationship between internet addiction and sleep quality among college students in Yogyakarta. The hypothesis proposed in this study is that there is a positive relationship between internet addiction and poor sleep quality among students in Yogyakarta. To test the research hypothesis, researchers conducted data retrieval using the internet addiction scale of Young (2013), namely the Internet Addiction Test (IAT), and the sleep quality scale from Yi (2009), namely the Sleep Quality Scale (SQS). Both scales were given to 325 students in Yogyakarta. The results of the data show the correlation coefficient $r=0.440$ with significance $p=0.000$ for internet addiction and sleep quality, so the hypothesis is accepted.
\end{abstract}

\section{Keywords: internet addiction, sleep quality, college students}

\section{INTRODUCTION}

Internet addiction is defined as a behavioral addiction, which involves the use of online applications with excessive usage and has a negative or detrimental impact on the individual's life [1]. A person can be said to experience internet addiction if the time spent using the internet outside of work matters reaches above normal levels or interferes with daily activities and causes a decrease in work productivity and one's learning achievement [2].

The use of the internet for students in Indonesia has been mentioned by the Indonesian Internet Service Providers Association (APJII) through the results of a 2016 survey. APJII states that the use of the internet by students reaches $89.7 \%$ [3]. The results of another survey were also mentioned by Ministry of Communication and Information Technology that internet users in Indonesia reached 82 million users in 2014 [4].

Some of the advantages of using the Internet to students ara as a communication medium, a medium of exchange of data, to search for information and data, and the community benefits [5]. Although it has benefits, the internet can also be dangerous for its users if it puts the internet at the center of its life [6]. Other research pointed that the internet is an important issue among students [7]. The benefits offered by the internet can cause users to become addicted because, according to a neurological perspective, the basis of addiction is an activity that is often done by humans and accepted by the brain [8]. As long as the activity is fun, dopamine in the brain will be active, and if the activity continues to be repeated and produces fun things, it will be strengthened by the brain and causes the brain to want to continue doing it again.
Previous researchers have met cases that often occur among students. A survey regarding internet addiction in college students showed that $43 \%$ of 119 participants used the internet more than 5 hours a day. $36 \%$ of participants stated that when using the internet, they felt engrossed in being unable to control their internet usage, while another $28 \%$ said that when accessing the internet, it took longer than they expected [9]. Another study found that $15.2 \%$ of total student subjects in China experienced internet addiction [10].

In early stage of this study, interviews were conducted to two people, each male, and female, who were pursuing undergraduate studies in Yogyakarta. The male subject stated that during the last six months in one day, the subject had at least accessed the internet for 12 hours, i.e. $8 \mathrm{pm}$ to $8 \mathrm{am}$. While female subjects can access the internet for 16 hours a day, from noon to $4 \mathrm{am}$. One category of person can be said to experience internet addiction is if he accesses the internet for at least 6 hours per day for at least three consecutive months [11]. In addition, both subjects have almost the same sleeping hours, i.e. starting from around 5 in the morning until 12 noon, this is a difficulty for both subjects while still taking lecture classes, male subjects told me that he was often late for college and did not even go to college because he woke up oversleep from playing games at night while the female subject prefers to sleep after returning from college rather than doing other activities if he accesses the internet until the morning. Female and male subjects have differences in accessing the internet, male subjects prefer to play online games, and female subjects more often access YouTube, streaming movies, and chat.

Besides the benefits of the internet that have been explained above, the internet also has negative impacts on its users. In a study in Hong Kong on Chinese teenagers with 719 participants, $17.2 \%$ of participants experienced addiction to the internet, more than half of the participants or $51.7 \%$ of participants experienced insomnia and $58.9 \%$ experienced depression [12]. The relatively same results were also explained by a research on the relationships of internet addiction, sleep quality, and depression in students in Nepal [13]. The teenagers or students have a large percentage of experiencing internet addiction, poor sleep quality, depression, or at least experiencing one of these three things.

\section{LITERATURE REVIEW}

A person can be said to experience internet addiction if he accesses the internet for at least 6 hours per day for at least three consecutive months [11]. A research conducted by conducted on students in China, shows that internet addiction 
is associated with the highest tendency towards depression and low self-esteem scores [14]. Another study also found that by adjusting age, sex, ethnicity, socioeconomic class, and family education, the use of social media was associated with psychological distress [15].

Factors that contribute to internet addiction can be categorized as internal and external to the individual. Internal factors of internet addiction include self-esteem [16], gender [17], loneliness [16], poor sleep quality [9] and aggression [18]. While the external factors of internet addiction are the family [19], peers [20], and social support [20].

Sleep quality is defined as the degree of excellent or superior sleep [21]. Another states that the quality of sleep is a condition in which the sleep experienced by a person produces freshness and fitness when awakened [22]. Besides, sleep quality is also defined as a state where sleep experienced by individuals can provide freshness and fitness when awakened from sleep [23].

The following are previous studies related to internet addiction and sleep quality. Among them are the results of research conducted in Vietnamese youth resulting in $21.2 \%$ of respondents diagnosed with internet addiction, $26.7 \%$ of respondents experiencing internet addiction also claimed to have difficulty sleeping, and $77.2 \%$ of receptive respondents seeking medical treatment [24]. Another study showed that $74.1 \%$ of students experienced internet addiction, $23.9 \%$ experienced severe addiction, and $2 \%$ experienced very severe addiction [25]. Other research states that internet messaging, web surfing, and playing online games were associated with a reduction in sleep duration, while using the internet for academic needs could improve the quality of one's sleep [26]. Furthermore, previous research related to sleep quality found that physical and mental symptoms can arise due to poor sleep quality, especially the critical thing found by researchers is the relationship between the appearance of physical and mental symptoms to poor sleep quality appear in young adults [27]. Previous studies have mostly focused on students and adolescents, not many studies related to internet addiction and sleep quality conducted on students.

After explaining some of the above about the relationship between internet addiction and sleep quality, this paper intends to examine further whether there is a link between internet addiction and sleep quality in students in Yogyakarta. Internet addiction can be defined as an impulse control disorder that does not involve drugs or alcohol [28]. According to other researchers, internet addiction is defined as a syndrome characterized by spending a lot of time using the internet and not being able to control its use when online [29]. Another definition mentioned that internet addiction is defined as behavioral addiction which involves the use of online applications with excessive usage and adversely affects the life of the individual [1].

Some aspects of internet addiction that are compatible with the Young's Internet Addiction Test (IAT) measurement tools, as follows [30]:

a. Salience. Individuals are too busy with the internet, and lose interest in doing other activities and / or socializing with others. This aspect also states that people who are addicted to the internet usually use the internet as a form of escape from their thoughts and feelings that life without the internet will be boring, empty, and not fun.

b. Excessive use. This indicates that individuals are involved in excessive online behavior and compulsive internet use, and cannot control the time they spend online. In this aspect, people who are addicted to the internet will become depressed, panicked, or even angry if forced to stay away from the internet.

c. Neglecting work. Work performance, academics, or productivity is disrupted because they prefer to be online and the subject is more defensive concerning internet usage time.

d. Anticipation. This indicates that individuals often think that they are online while not accessing the internet, and forced to use the internet.

e. Lack of control. Individuals have problems controlling their time to access the internet, often accessing the internet more than the specified time

f. Neglecting social life. Make use of relationships from the virtual world to overcome problems or reduce mental tension and stress and form relationships in cyberspace, which can disrupt relationships in the real world.

The factors affecting internet addiction consists of external and internal factors. Internal factors of internet addiction are:

a. Gender. The internet addiction score of women is lower than the internet addiction score of men [30].

b. Pride. Self-esteem is associated with time management problems and interpersonal problems. Therefore selfesteem is said to have an indirect effect on internet addiction [16].

c. Loneliness. Lonely people find it difficult to regulate compulsive internet use, have difficulty managing time, and care for their health [16].

d. Aggression. Aggression has a positive correlation with the addiction to playing online games [18].

e. Poor sleep quality. Poor sleep quality is of concern to doctors because it can affect internet addiction in individuals [8].

External factors can also influence internet addiction such as:

a. Family. Parent attitudes, communication in the family, cohesion in the family, and exposure to family violence are related to internet addiction [18].

b. Peers. Peers can influence addiction to the internet. The lower the pressure from peers, one's internet addiction can decrease [20].

c. Social support. The more support from parents and teachers, the score of internet addiction in adolescents can decrease [20].

Sleep quality has many aspects such as [31]:

a. Daytime dysfunction. The body does not function normally during the daytime. Poor sleep quality at night can cause bodily dysfunction during the day including difficulty thinking, difficulty concentrating, being less 
interested in work, feeling sleepy when on the move, and dizzy.

b. Restoration after sleep. Feelings are better after waking up, such as fatigue that disappears after sleep, feels more energetic, and feels fresher.

c. Difficulty in falling asleep. Difficulties when trying to sleep, such as always feeling restless when trying to sleep, and often wake up at night and cannot go back to sleep again.

d. Difficulty in getting up. Difficulty getting out of bed like always feeling less after waking up and hoping to go back to sleep again.

e. Sleep satisfaction. Feel satisfied when waking up and have enough sleep.

f. Difficulty in maintaining sleep. Difficulty keeping or maintaining sleep at the same level. Usually, people who have difficulty maintaining sleep will quickly wake up when they are sleeping when they hear the sounds around them.

The hypothesis of this study is that there is a positive relationship between internet addiction and sleep quality among college students in Yogyakarta. The higher the addiction to the Internet, the poorer the quality of sleep and vice versa.

\section{METHODS}

The purpose of this study was to determine the relationship between internet addiction and sleep quality in students in Yogyakarta. The subjects used in this study were 325 people. The research subjects were students who were studying in the city of Yogyakarta.

This study uses an internet addiction scale called Young's Internet Addiction Test. As for the sleep quality scale using Yi's Sleep Quality Scale. Researchers use analysis statistics to perform hypothesis testing is used to determine the relationship between internet addiction and sleep quality. Researchers use analysis statistics with the help of the program SPSS as a method of data analysis. The analysis used in this study is the Product Moment Correlation Test from Pearson.

\section{RESULTS}

Based on the results of analytical tests that have been carried out, then obtained a description of research data from the internet addiction scale and sleep quality scale as follows:

Table 1 Categorization in research for internet addiction variable.

\begin{tabular}{cccc}
\hline Categorization & $\begin{array}{c}\text { Normalization } \\
\text { Score }\end{array}$ & Frequency & Percentage \\
\hline Very low & $\mathrm{X}<24$ & 54 & $16.61 \%$ \\
Low & $24 \leq \mathrm{X}<31$ & 74 & $22.77 \%$ \\
Middle & $31 \leq \mathrm{X}<38$ & 66 & $20.31 \%$ \\
High & $38 \leq \mathrm{X}<44.8$ & 66 & $20.31 \%$ \\
Very high & $\mathrm{X} \geq 44.8$ & 65 & $20 \%$ \\
\hline
\end{tabular}

Based on the table above, the internet addiction scale shows that of 325 subjects 54 subjects were included in the very low category with a percentage of $16.61 \%, 74$ subjects were included in the low category with a percentage of $22.77 \%, 66$ subjects were included in the moderate category with a percentage of $20,31 \%, 66$ subjects were included in the high category with a percentage of $20.31 \%$, and 65 subjects were included in the very high category with a percentage of $20 \%$.

Table 2 Categorization in research for sleep quality variable.

\begin{tabular}{cccc}
\hline Categorization & $\begin{array}{c}\text { Normalization } \\
\text { Score }\end{array}$ & Frequency & Percentage \\
\hline Very low & $\mathrm{X}<22$ & 56 & $17.23 \%$ \\
Low & $22 \leq \mathrm{X}<27$ & 60 & $18.46 \%$ \\
Middle & $27 \leq \mathrm{X}<31$ & 65 & $20.00 \%$ \\
High & $31 \leq \mathrm{X}<37.8$ & 79 & $24.31 \%$ \\
Very high & $\mathrm{X} \geq 37.8$ & 65 & $20.00 \%$ \\
\hline
\end{tabular}

Based on the table above, the sleep quality scale shows that of 325 subjects there were 56 subjects that were included in the very low category with a percentage of $17.23 \%, 60$ subjects were included in the low category with a percentage of $18.46 \%, 65$ subjects were included in the moderate category with a percentage of $20 \%, 79$ subjects were included in the high category with a percentage of $24.31 \%$, and 65 subjects were included in the very high category with a percentage of $20 \%$.

The assumption test is carried out as a prerequisite that must be met before carrying out a hypothesis test. The assumption tests include the normality test and the linearity test. This assumption test is carried out with the help of a statistical program in SPSS version 16 for windows. A normality test is done to find out the data distribution of each research variable. After analysis, data can be said to be normal if the coefficient of significance $>0.05$. The following table is the result of a normality test of resilience and social support variables:

Table 3 Research data normality test results.

\begin{tabular}{ccc}
\hline Variable & $\begin{array}{c}\text { Coefficient of } \\
\text { significance }(p)\end{array}$ & Decision \\
\hline Internet addiction & 0.000 & $\begin{array}{c}\text { Not normally } \\
\text { distributed }\end{array}$ \\
Sleep quality & 0.021 & $\begin{array}{c}\text { Not normally } \\
\text { distributed }\end{array}$ \\
\hline
\end{tabular}

Based on the results of the normality test in the table above, it can be seen that the data from the internet addiction variable is $0,000(\mathrm{p}<0.05)$, this means that the data distribution of the internet addiction variable is not normally distributed. Whereas for the sleep quality variable has a significant coefficient of 0.021 ( $\mathrm{p}<0.05$ ), it can be interpreted that data from sleep quality support variables are not normally distributed. 
The linearity test aims to see the linear relationship between the two variables. Both variables can be said to have a linear relationship if the significance coefficient value of linearity $(\mathrm{p}<0.05)$ and the value of deviation from linearity p> 0.05. The following table is the result of the variable resilience and social support after linearity testing:

Table 4 Linearity test results for internet addiction and sleep quality variables.

\begin{tabular}{ccccc}
\hline Variable & Linearity & $\begin{array}{c}\text { Linearity } \\
\text { coefficient } \\
(F)\end{array}$ & $\begin{array}{c}\text { Coefficient } \\
\text { of } \\
\text { significance } \\
(p)\end{array}$ & Decision \\
\hline $\begin{array}{c}\text { Internet } \\
\text { addiction } \\
\text { Sleep } \\
\text { quality }\end{array}$ & $\begin{array}{c}\text { L } \\
\text { Linearity }\end{array}$ & 75.384 & 0.000 & Linear \\
& $\begin{array}{c}\text { F } \\
\text { Deviation } \\
\text { from } \\
\text { Linearity }\end{array}$ & 0.918 & 0.621 & $\begin{array}{c}\text { Does not } \\
\text { deviate } \\
\text { from the } \\
\text { straight } \\
\text { line }\end{array}$ \\
\hline
\end{tabular}

Based on the results of the linearity test between internet addiction variables and sleep quality, the results show that the linearity value between internet addiction variables and sleep quality has a value of $F=75,384$ and $p=0,000(p<0.05)$ and the value of deviation from linearity $F=0.918$ and $p=0.621$ ( $p>0.05$ ). This means that the variables of internet addiction and sleep quality have a linear relationship and do not deviate from the straight line.

After testing the normality and linearity, it is known that the data in this study have abnormal data distribution and the linearity test of internet addiction variables and sleep quality have a linear relationship and do not deviate from the straight line. This is because one of the assumption tests is not met, then the hypothesis test used is the Spearman's Rho correlation technique. The hypothesis in this study is that there is a positive relationship between internet addiction and sleep quality in students in Yogyakarta. The higher the internet addiction, the higher the quality of sleep. The table below is the result of the hypothesis test:

Table 5 Hypothesis test results.

\begin{tabular}{ccccc}
\hline Variable & $r$ & $p$ & $R^{2}$ & Decision \\
\hline $\begin{array}{c}\text { Internet } \\
\text { addiction } \\
\text { and }\end{array}$ & 0.437 & 0.000 & 0.190 & Significant \\
$\begin{array}{c}\text { sleep } \\
\text { quality }\end{array}$ & & & & \\
\hline
\end{tabular}

After analyzing the correlation between internet addiction variables and sleep quality, it can be said the results of the correlation coefficient $(r)=0.440$ and $p=0.000(p<0.05)$. This shows that there is a positive correlation between variables of internet addiction and social support for students in Yogyakarta, it can be said that the higher the level of internet addiction, the higher the level of sleep quality is low for students in Yogyakarta. So it can be concluded that the hypothesis in this study was accepted.

\section{DISCUSSION}

This study aims to determine whether there is a relationship between internet addiction and sleep quality in students who are studying in Yogyakarta. After an analysis using the Spearman Rho correlation technique, it was found that there was a positive correlation between the variables of internet addiction and sleep quality for students in Yogyakarta. This finding is in line with previous studies [7, 24]. This means that the higher the internet addiction is experienced, the poorer the sleep quality. Therefore, it can be concluded that the hypothesis in this study was accepted.

This study found useful contribution of the internet addiction variable to the sleep quality variable [19.00\%]. This means that $81.00 \%$ effective contribution of the variable sleep quality is influenced by other factors not examined in this study. This study found a correlation between aspects of internet addiction in the form of negative work with sleep quality. The significance value between sleep quality and negative work is equal to $\mathrm{p}=0,000(\mathrm{p}<0.05)$, with a coefficient of determination equal to 0.320 . The contribution of sleep quality to negative work is $32.0 \%$. This is reinforced by previous studies examined the relationship between sleep quality and academic achievement [32].

The next finding is a correlation between sleep quality aspects in the form of daytime dysfunction with internet addiction. The significance value between internet addiction and daytime dysfunction is $\mathrm{p}=0,000(\mathrm{p}<0.05)$ with a coefficient of determination equal to 0.370 . Other research reinforces the contribution of internet addiction to daytime dysfunction in the amount of $37.0 \%$. It also stated that there is a relationship between internet addiction and daytime sleepiness [33]. Another study found that there is a strong relationship between internet addiction and excessive daytime sleepiness in adolescents [34].

The next aspect of sleep quality is difficulty in falling asleep, which has a strong relationship with internet addiction. The significance value between internet addiction and difficulty in falling asleep is equal to $\mathrm{p}=0,000(\mathrm{p}<0.05)$ with a coefficient of determination of 0.335 . The contribution of internet addiction to difficulty in falling asleep is $33.5 \%$ This is in line with previous finding which states that there is a strong relationship or correlation between internet addiction and insomnia [35].

In this study, a correlation test was performed based on sex, and it was found that the results of the correlation test were that there was a positive correlation between variables of internet addiction and sleep quality in male and female subjects. Other research also stated that when viewed from social roles, men are more addicted to the internet when compared to women [36].

Other findings are the results of different tests conducted on the internet addiction variable on sex, on the internet addiction, there was no significant difference between men and women $(\mathrm{t}=0.712$ and $\mathrm{p}=0.477(\mathrm{p}>0.05))$. However, referring to the results of the descriptive analysis shows that internet addiction in men is higher than women, this can be seen from the mean values in men $(M=35.4921)$ and women $(\mathrm{M}=34.4523)$. This finding is not in line with other research [37] which states that internet addiction in women is higher than men. 
In this study also conducted a different test on the variable of sleep quality on sex, which obtained the value of $t=1,138$ and $p=0.256(p>0.05)$. This shows that there is no difference in the quality of sleep experienced by men and women. However, referring to the results of the descriptive analysis shows that men have higher sleep quality than women. This can be seen from the mean value held by men $(M=30.2857)$ and women $(M=29.1307)$. These findings are not in line with research [38] which states that women own higher sleep quality.

Judging from the status of the subject's residence, as many as 251 subjects with a percentage of $77.23 \%$ lived in boarding houses, 69 subjects with a percentage of $21.23 \%$ lived with parents, and five subjects with a percentage of $1.54 \%$ lived in the dormitory. Judging from the status of residence, it can be seen that the role of parents is significant for internet addiction to students. It is crucial to direct parents to pay more attention and take intervention steps to reduce the internet addiction [39].

\section{CONCLUSION}

Based on research that has been done, it can be concluded that there is a positive relationship between internet addiction and low sleep quality in students in Yogyakarta. This shows that the higher the internet addiction to students, the lower the sleep quality for students in Yogyakarta. Vice versa, the lower the internet addiction, the higher the sleep quality for students in Yogyakarta.

Based on the results obtained from this study, suggestions for further works can be aimed at the following. Students are expected to be able to control the use of the internet so that it does not cause addiction, and still pay attention to things around such as academic, social, personal, and others. Judging from the limitations in this study, the next researchers are expected to be able to limit the subject to subjects who are genuinely experiencing internet addiction. Besides, further researchers are expected to increase the number of subjects and to collect data evenly in Yogyakarta.

\section{REFERENCES}

[1] D. J. Kuss, A. J. Van de Rooji, G. W. Shorter, M. D. Griffiths, \& D. Van de Mheen, "Internet addiction in adolescents: Prevalence \& risk factors", Computers in Human Behavior, vol. 29, no. 5, pp. 1987-1996, 2013.

[2] S. Yuniar, "Ketergantungan pada internet: Game online, video game, dan sejenisnya", Anima: Indonesian Psychological Journal, vol. 23, no. 2, pp. 180-183, 2008.

[3] Asosiasi Penyelenggara Jasa Internet Indonesia, Survey Internet APJII 2016, Jakarta, Indonesia: Asosiasi Penyelenggara Jasa Internet Indonesia, 2016. Available: https://apjii.or.id/content/read/39/264/Survei-InternetAPJII-2016.

[4] Kominfo, Kemkominfo: Pengguna Internet di Indonesia Capai $82 \quad$ Juta, $2014 . \quad$ Available: https://kominfo.go.id/index.php/content/detail/3980/Ke mkominfo\%3A+Pengguna+Internet+di+Indonesia+Cap ai+82+Juta/0/berita_satker.

[5] A. N. Qomariyah, "Perilaku Penggunaan Internet pada Kalangan Remaja di Perkotaan (Studi Deskriptif Tentang Perilaku Penggunaan Internet Siswa-siswi SMP Negeri 37 Surabaya, SMP IMKA/YMCA-1 Surabaya, SMA Negeri 5 Surabaya, SMA Trisila Surabaya)", Undergraduate thesis, Fakultas Ilmu Sosial dan Ilmu Politik, Universitas Airlangga, 2009. Available: http://repository.unair.ac.id/18241/
[6] J. J. Kandell, "Internet addiction on campus: The vulnerability of college students", CyberPsychology \& Behavior, vol. 1, no. 1, pp. 11-17, 1998.

[7] U. Alaettin. T. Mustafa. A. Didem. A. Emine. A. M. Serhat. I. A. Burcu. K. Tugce. \& B. Necati. "Internet addiction and sleening aualitv among college students in West Turkev". Research .Iournal of Educational Sciences, vol. 4, no. 7, pp. 1-8, 2016.

[8] L. Perdew, Internet addiction, Minnesota, US: Abdo Publishing, 2015.

[9] U. Maiorsv. C. D. Pratiwi. M. Sanutra. U. Manurung. O. K. Rini. \& W. Rahardio. Kecanduan Internet Pada Mahasiswa. 2013. Available: httns://www.academia.edu/30096301/KECANDUAN_I NTERNET_PADA_MAHASISWA

[10] X. Chi, L. Lin, \& P. Zhang, "Internet addiction among college students in China: Prevalence and psychosocial correlates," Cyberpsychology, Behavior, and Social Networking, vol. 19, no. 9, pp. 567-573, 2016.

[11] R. Tao, X. Huang, H. Zhang, Y. Zhang, \& M. Li, "Proposed diagnostic criteria for internet addiction", Addiction, vol. 105, no. 3, pp. 556-564, Mar. 2010.

[12] L. M. Cheung \& W. S. Wong, "The effects of insomnia and internet addiction on depression in Hong Kong Chinese adolescents: An exploratory cross-sectional analysis", Journal of Sleep Research, vol. 20, no. 2, pp. 311-317, 2011.

[13] P. M. Bhandari, D. Neupane, S. Rijal, K. Thapa, S. R. Mishra, \& A. K. Poudyal, "Sleep quality, internet addiction, and depressive symptoms among undergraduate students in Nepal", BMC Psychiatry, vol. 17, no. 106, pp. 1-8, 2017.

[14] J. Nie. W. Zhang. \& Y. Liu. "Exnloring denression. selfesteem and verbal fluencv with different degrees of internet addiction among Chinese college student", Comprehensive Psychiatry, vol. 72, pp. 114-120, 2017.

[15] H. S. Kayinga \& H. A. Hamilton, "Social networking sites and mental health problems in adolescent: the mediating role of cyberbullying victimization", European Psychiatry, vol. 30, pp. 1021-1027, 2015.

[16] B. Bozolglan, V. Demirer, \& I. Sahin, "Loneliness, selfesteem, and life satisfaction as predictors of Internet addiction: A cross-sectional study among Turkish university students", Scandinavian Journal of Psychiatry, vol. 54, pp. 313-319, 2013.

[17] C. H. Ko, J. Y. Yen, C. C. Chen, S. H. Chen, \& C. F. Yen, "Gender differences and related factors affecting online gaming among Taiwanese adolescents", The Journal of Nervous and Mental Disease", vol. 193, no. 4, pp. 273-277, 2005.

[18] E. J. Kim, K. Namkoong, T. Ku, \& S. J. Kim, "The relationship between online game addiction and aggression, self control, and narcissistic personality traits", European Psychiatry, vol. 23, pp. 212-218, 2008.

[19] S. K. Park. J. Y. Kim. \& C. B. Cho. "Prevalence of Internet addiction and correlations with familv factors among South Korean adolescents," Adolescence, vol. 43, no. 172, pp. 895-909, 2008.

[20] B. K. Esen \& M. Gundogdu, "The relationship between internet addiction, peer pressure, and perceived social support among adolescents", The International Journal of Educational Researchers", vol. 2, no. 1, pp. 29-36, 2010.

[21] H. Yi. K. Shin. \& C. Shin. "Develonment of the sleen aualitv scale". Journal of Sleep Research, vol. 15, pp. 309-316, 2006.

[22] F. Nashori \& R. R. Diana. "Perbedaan kualitas tidur dan kualitas mimni antara mahasiswa laki-laki dan mahasiswa neremnuan". Indonesian Psychological Journal, vol. 2, no. 2, pp. 77-88, 2005.

[23] K. Khasanah \&W. Hidayati, "Kualitas tidur lansia Balai Sosial "Mandiri" Semarang. Jurnal Nursing Studies, vol. 1 , no. 1 , pp. 189-196, 2012. 
[24] M. W . Zhang B. X. Tran N. D. Hinh. H. L. T Nouven T. D. Tho. C. Latkin. \& R. C. Ho. "Internet addiction and sleen aualitv among Vietnamese vouths", Asian Journal of Psychiatry, vol. 28, pp. 15-20, 2017.

[25] P. Abolghasem, M. Eftekhari, S. Rezania, M. Jafarisani, R. Soleimani, \& A. Khalafi, "Studying the relationship between quality of sleep and addiction to internet among students", Nova Journal of Medical and Biological Science, vol. 5, no. 3, pp. 1-7, 2016.

[26] F. Canan, O. Yildirim, G. Sinani, O. Ozturk, T. Y. Ustunel, \& A. Ataoglu, "Internet addiction and sleep disturbance symptoms among Turkish high school students", Sleep and Biological Rhythms, vol. 11, pp. 210-213, 2013.

[27] C. Augner, "Associations of subjective sleep quality with depression score, anxiety, physical symptoms and sleep onset latency in students", Central European Journal of Public Health, vol. 19, no. 2, pp. 115-117, 2011.

[28] K. Young. "Internet addiction: The emergence of a new clinical disorder." Cvher Psychology \& Behavior, vol. 1, no. 3, pp. 237-244, 1998.

[29] H. Nurmandina. D. Wigati. \& L. Masluchah. "Hubungan antara kemamnuan sosialisasi dengan kecanduan ieiaring sosial.".Jurnal Penelitian Psikologi, vol. 4, no. 2, pp. 107-119, 2013.

[30] L. Widyanto \& M. McMurran, "The psychometric properties of the internet addiction test," CyberPsychology \& Behavior, vol. 7, no. 4, pp. 443-450, 2004.

[31] H. Yi. K. Shin. J. Kim. J. Kim. J. Lee. \& C. Shin. "Validitv and reliabilitv of sleen dualitv scale in subiects with obstructive sleen annea svndrome", Journal of Psychosomatic, vol. 66, pp. 85-88, 2009.

[32] H. Nilifda. Nadimir. \& Hardisman. "Hubungan kualitas tidur dengan prestasi akademik mahasiswa Program
Studi Pendidikan Dokter Angkatan 2010 FK Universitas Andalas. Jurnal Kesehatan Andalas, vol. 5, no. 1, pp. 243-249, 2016.

[33] M. Hadadvand, L. Karimi, Z. A. Validkandi, P. Ramezanian, H. Mehrabi, H. R. Ahmadi, \& S. Z. Mohammadi, "The relationship between internet addiction and sleep disorders in students," Jurnal of Health and Care, vol. 15, no. 4, pp. 39-49, 2013.

[34] K. Choi, H. Son, M. Park, J. Han, K. Kim, B. Lee, \& H. Gwak, "Internet overuse and excessive daytime sleepiness in adolscents," Psychiatry and Clinical Neurosciences, vol. 63, pp. 455-462, 2009.

[35] N. Dewi, "Hubungan antara kecanduan internet dan kecemasan dengan insomnia pada mahasiswa S1 FK UNS yang sedang skripsi", Undergraduate thesis, Fakultas Kedokteran, Universitas Sebelas Maret. Available: https://eprints.uns.ac.id/4667/

[36] M. Akdag, B. S. Yilmaz, U. Ozhan, \& I. San, "Investigation of university students' internet addiction terms of several variables (Inonu University sample)", Inonu University Journal of the Faculty of Education, vol. 15, no. 1, pp. 73-96, 2014.

[37] J. Y. Yen. C. H. Ko. C. F. Yen. C. S. Chen. \& C. C. Chen. "The association between harmful alcohol use and internet addiction among college students: Comparison of nersonalitv." Psvchiatrv and Clinical Neurosciences, vol. 63, pp. 218-224, 2009.

[38] Y. Fatima, S. A. R. Doi, J. M. Najman, \& A. A. Mamun, "Exploring gender difference in sleep quality of young adults: findings from a large population study", Clinical Medical \& Research, vol. 14, no. 3-4, pp. 138-144, 2006.

[39] Q. Ding, D. Li, Y. Zhou, H. Dong, \& J. Luo, "Perceived parental monitoring and adolescent internet addiction: A moderated mediation model", Addictive Behaviors, vol. 74, pp. 48-54, 2017. 